\title{
VARIASI PENGGUNAAN REKONTRUSI ALGORITMA FBP, iDose4 DAN ITERATIVE MODEL RECONTRUCTION (IMR) TERHADAP KUALITAS CITRA MCST THORAK LOW DOSE UNTUK MENDETEKSI NODUL PARU
}

\author{
$\underline{{ }^{1} \text { Siti Anikmah, }{ }^{2} \text { Yeti Kartikasari, }{ }^{3} \text { Ary Kurniawati }}$ \\ ${ }^{1}$ Radiographer of RSUD RAA Soewond, Pati, Indonesia \\ ${ }^{2,3}$ Poltekkes Kemenkes Semarang, Indonesia \\ Corresponding author: Siti Anikmah \\ Email: mamafiona80@gmail.com \\ Received: written by editor; Revised: written by editor; Accepted: written by editor \\ October $10^{\text {th }} 2020$
}

\begin{abstract}
Background: Pulmonary nodules are often found accidentally when thorax imaging is done. The size and rate of nodule growth are the most important predictors of imaging for malignancy. When the low dose protocol applied to the thorax MSCT will affect image quality, such as increased noise and decreased spatial resolution, so that the detection of nodules becomes less accurate. For noise limitation the reconstruction of the FBP, iDose4 and IMR algorithm is used. The purpose of this literature study is to evaluate variations in the FBP, iDose4 and IMR algorithm in improving image quality.

Methods: This method is a qualitative research with a descriptive approach using comprehensive literatures studies

Results: The result show that noise reduction is highest at IMR and lowest at FBP. The highest number of detected nodules on IMR especially for solid nodules $<4 \mathrm{~mm}$ and the lowest on FBP. Pathological findings with the best quality on IMR and quality are limited to FBP. Visibility of normal and abnormal findings, iDose4 is better than IMR and FBP especially for reticular patterns. Effective doses are reduced by $44 \%$ to $59 \%$ based on this literature study. In clinical practice, IMR shows the potential for pathological recovery at low dose level and IMR can improved measured image quality based on noise, high contrast spatial resolution and low contrast detectability.

Conclusion: So IMR is the most effective algorithm applied for scanning low dose MSCT thorax for detection of pulmonary nodules.
\end{abstract}

Keyword: Thorax MSCT, Low Dose, FBP, iDose4, IMR, Nodule

\section{Pendahuluan}

Kemajuan teknis dalam pemindai Computed Tomography sangat meningkatkan akurasi diagnostik sehingga menaikkan frekuensi permintaan pemeriksaan MSCT, namun sekaligus juga meningkatkan kekhawatiran bahwa pasien akan menerima tingkat radiasi pengion yang berlebihan. Baik radiografer maupun vendor selalu berinovasi untuk mengurangi paparan dosis radiasi selama pemeriksaan dengan tetap mempertahankan kualitas gambar (Sakhnini, 2018).

Nodul paru sering ditemukan secara tidak sengaja ketika pencitraan MSCT toraks dilakukan untuk tujuan skrining ataupun karena alasan lain (Jin dkk., 2018). Ukuran dan laju pertumbuhan nodul adalah prediktor radiografi yang paling penting untuk deteksi kanker dan metastasis paru (Snell, 2012).

Upaya mengoptimalkan parameter akuisisi dilakukan salah satunya dengan cara penggunaan protokol low dose. Protokol low dose dipilih untuk pencitraan nodul paru karena udara di paru-paru menghasilkan lebih banyak kontras daripada jaringan disekitarnya sehingga deteksi patologis tidak lagi tergantung noise gambar yang diakibatkan dosis radiasi yang rendah (Nagayama dkk., 2018). Namun penggunaan low dose ini ternyata akan mempengaruhi kualitas citra, yang ditandai dengan meningkatnya noise dan penurunan resolusi spasial sehingga deteksi nodul menjadi kurang akurat. Salah satu upaya yang 
dilakukan untuk meningkatkan kualitas citra pada kondisi dosis rendah tersebut adalah penggunaan rekonstruksi algoritma (Patino dkk., 2015). Penggunaan rekonstruksi algoritma pada chest $\mathrm{CT}$ dilaporkan mengurangi noise dan meningkatkan kualitas citra (Kim dkk., 2015).

Rekonstruksi algoritma adalah prosedur matematis (algoritma) yang digunakan dalam merekontruksi gambar. Rekonstruksi algoritma yang dipilih semakin tajam, maka resolusi citranya pun akan menjadi tinggi. Hal ini terjadi karena kemampuan filter dalam merekonstruksi pixel pixel yang berdekatan akan semakin jelas perbedaanya sehingga gambaran tulang, soft tissue dan jaringan - jaringan lainnya dapat dengan jelas dibedakan pada layar monitor (Seeram, 2016).

Kualitas citra adalah semua faktor yang berhubungan dengan akurasi dalam menampakkan struktur dan jaringan ke dalam citra (Patino dkk., 2015). Komponen yang mempengaruhi kualitas citra meliputi spasial resolusi, kontras resolusi, noise dan artefak (Seeram, 2016). Pada dasarnya semua MSCT telah menggunakan rekonstruksi standar yaitu Filtered Back Projection (FBP). Meskipun kinerjanya dapat diterima secara keseluruhan, citra yang direkonstruksi dengan FBP masih menghasilkan image noise yang tinggi, streak artefak dan low contrast detectability yang rendah pada klinis tertentu (Geyer dkk., 2015).

Generasi Philips iDose4 hadir setelah FBP dengan menawarkan kualitas citra yang lebih baik dengan mereduksi dosis pasien. Tahapan rekonstruksi dengan metode ini adalah menganalisis data proyeksi, mengidentifikasi dan memperbaiki efek noise. Proses ini memastikan gradient atenuasi obyek tetap ada sehingga spasial resolusi tetap baik (Paper, 2013).

Generasi advance yang hadir setelah iDose4 adalah Iterative Model Reconstruction (IMR), sebuah teknik rekonstruksi algoritma yang menggunakan pendekatan model berbasis ilmu pengetahuan. Sistem kerjanya dengan melakukan rekonstruksi CT image model, dengan dua langkah proyeksi maju dan mundur. Langkah maju mundur ini diulang beberapa kali sampai tingkat koreksi menjadi kecil. Hasilnya adalah gambar yang benar - benar free noise, low dose dan meningkatnya low contrast detectability (Halliburton, 2016).

Studi literatur ini akan mengevaluasi variasi algoritma FBP, iDose4 dan IMR terhadap kualitas citra pada pemeriksaan MSCT toraks low dose untuk mendeteksi nodul paru. Enam artikel terpilih memenuhi kriteria inklusi yakni Yan
(2019),Zhang(2018), Xin (2018) De Margerie (2016) Laqmani (2016) dan Denharder (2015)

\section{Metode}

Jenis penelitian ini adalah penelitian kualitatif dengan pendekatan deskriptif menggunakan studi literatur. Studi dilaksanakan dalam rentang waktu April sampai Mei 2020

\section{Hasil dan Pembahasan}

Pada Penelitian tentang MSCT toraks low dose untuk deteksi nodul paru ini digunakan intervensi penggunaaan variasi rekonstruksi algoritma FBP, iDose4 dan IMR dengan modalitas MSCT Philips. Total pasien berdasar 6 jurnal yang dipakai adalah 548 pasien dengan klinis nodul paru, baik nodul yang diperoleh dari screening rutin maupun screening follow up (tuberculosis, malignant tumor post pengobatan, keganasan hematology dan nodul screening pneumonia)

Berdasarkan kajian jurnal, kualitas citra yang dimaksud dalam penelitian ini meliputi meliputi evaluasi noise, detectability lesi, visibilitas temuan normal dan abnormal, dan tingkat kepercayaan diagnostik serta evaluasi pengurangan dosis.

\section{a. Evaluasi Noise}

Berdasarkan Laqmani (2016) hasil pengukuran objektive image noise (OIN) seperti ditunjukkan pada Fig 1 sebagai berikut:

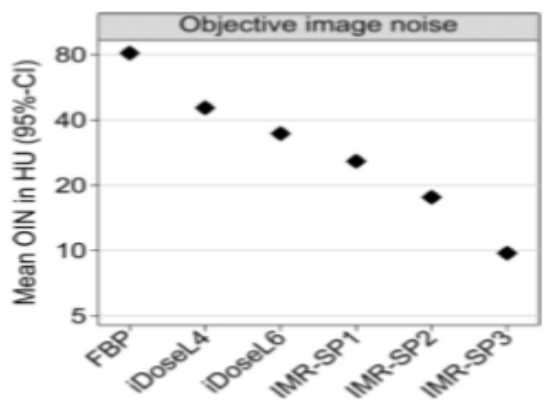

Gambar 1. Grafik plot pengukuran objektive image noise (Laqmani, dkk., 2016)

Pada Gambar 1. Pengukuran OIN yang menghasilkan noise tertinggi adalah FBP pada angka 80, nilai noise iDose4 pada rentang $35-40$ dan noise IMR lebih rendah pada 10 - 25

\section{b. Detectability Lesi (low contrast detectability)}

Berdasar Zhang (2018) pada pemindaian ultra low dose jumlah nodul terdeteksi pada IMR lebih tinggi daripada iDose4 dan FBP, terutama nodul padat dengan ukuran $<4 \mathrm{~mm}$. Keterdeteksian lesi 
pada kontras rendah dapat ditunjukkan pada Fig 2 berikut ini:

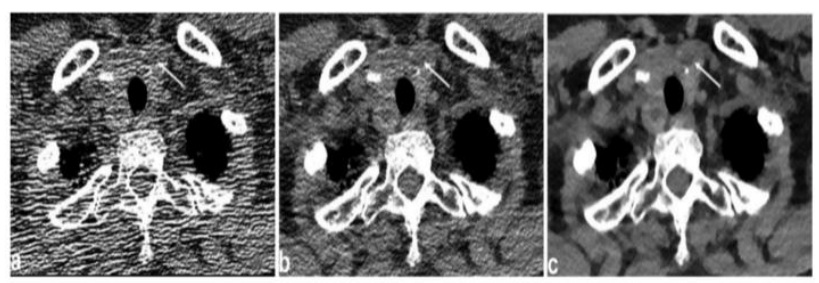

Gambar 2. Hasil citra MSCT toraks skrining kanker dengan pemindaian low dose yang direkonstruksi (a) FBP (b) iDose4 (c) IMR

(Zhang dkk,2018)

Pada Gambar 2 ditemukan nodul dengan kalsifikasi pada lobus kiri thyroid gland, sangat jelas dengan IMR, kurang jelas dengan iDose4 dan kurang jelas (kabur) pada FBP

c. Visibilitas temuan normal dan abnormal

Berdasar Laqmani (2016) FBP menduduki visibilitas terendah untuk semua temuan abnormal kecuali pola retikuler. IMR juga rendah untuk visibilitas ini karena meningkatnya level IMR mengakibatkan kaburnya pola retikuler sedang hingga berat. Sedangkan iDose4 memberikan visibilitas terbaik untuk pola retikuler seperti ditunjukkkan pada Fig 4 sebagai berikut :

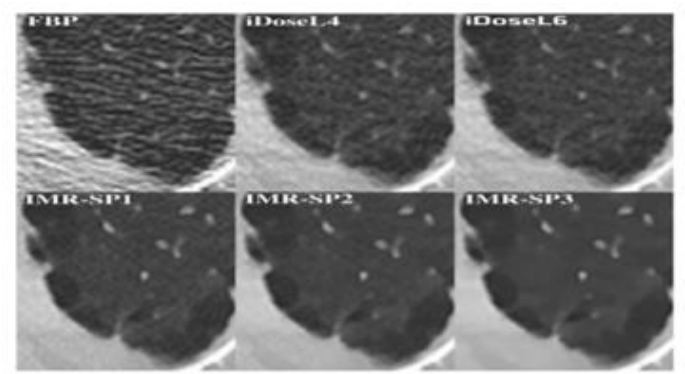

Gambar 3.Visibilitas temuan abnormal paru dengan pemindaian low dose yang direkonstruksi dengan FBP, iDose4 level 4, iDose4 level 6, IMR level 1, IMR level 2, IMR level 3 (Laqmani dkk., 2016)

\section{d. Tingkat kepercayaan diagnostik}

Berdasar Yan (2019), Zhang (2018), Xin (2018), Margerie (2016) pada pemindaian ultra low dose, nodul terdeteksi lebih baik dengan jumlah terdeteksi lebih tinggi terutama nodul padat $<4 \mathrm{~mm}$, visualisasi temuan patologis lebih baik dengan batas lesi tegas dan sangat jelas oleh IMR dibanding iDose4 dan FBP,

Berdasar hasil kajian studi literatur, IMR menduduki urutan tertinggi untuk tingkat kepercayaan diagnostik dibanding iDose4 dan FBP. IMR unggul dalam deteksi lesi pada kontras rendah, IMR unggul dalam visibiltas normal dan abnormal secara umum, IMR juga unggul dalam temuan lesi

\section{e. Evaluasi pengurangan dosis}

Berdasar Yan (2019) dosis efektif berkurang $59 \%$ dengan pemindaian ultra low dose dengan intervensi penurunan tegangan tabung $(\mathrm{kV})$ Berdasar Zhang (2018) dosis efektif berkurang 44 $\%$ pada pemindaian ultra low dose dengan intervensi penurunan arus tabung (mAs).

\section{Simpulan}

Hasil studi literatur menunjukkan bahwa pengurangan noise tertinggi pada IMR dan terendah pada FBP. Jumlah nodul terdeteksi tertinggi pada IMR terutama untuk nodul padat $<4$ mm dan deteksi terendah pada FBP. Temuan patologis dengan kualitas terbaik pada IMR dan kualitas terbatas pada FBP. Visibilitas temuan normal dan abnormal, iDose4 lebih baik dibanding IMR dan FBP terutama untuk pola reticuler. Tingkat kepercayaan diagnostik IMR tertinggi dan FBP terendah. IMR paling tinggi memperbaiki kualitas citra, kedua adalah iDose4 dan ketiga adalah FBP. Dosis efektif berkurang $44 \%$ sampai $59 \%$ berdasar studi literatur ini.

Karena IMR lebih unggul untuk temuan nodul dalam pemindaian dosis rendah, maka IMR adalah rekonstruksi algoritma paling efektif diterapkan menurut kajian jurnal dan dapat direkomendasikan untuk digunakan sebagai protokol MSCT toraks low dose untuk deteksi nodul paru di rumah sakit tempat sejawat bekerja.

\section{Daftar Pustaka}

Aurumskjöld, M.-L. D. (2017). Optimisation of image quality and radiation dose in computed tomography using iterative image reconstruction.

Den Harder, A. M., Willemink, M. J., Van Hamersvelt, R. W., Vonken, E. J. P. A., Milles, J., Schilham, A. M. R., Lammers, J. W., De Jong, P. A., Leiner, T., \& Budde, R. P. J. (2016). Effect of radiation dose reduction and iterative reconstruction on computer-aided detection of pulmonary nodules: Intra-individual comparison. European Journal of Radiology, 85(2), 346351.

https://doi.org/10.1016/j.ejrad.2015.12.003

Geyer, L. L., Schoepf, U. J., Meinel, F. G., Nance, J. W., Bastarrika, G., Leipsic, J. A., Paul, N. S., Rengo, M., Laghi, A., \& De Cecco, C. N. (2015). State of the Art: Iterative CT 
reconstruction techniques1. Radiology, 276(2), 339-357. https://doi.org/10.1148/radiol.2015132766

Halliburton, S. S. (2016). Advanced Reconstruction Methods on Philips CT Systems.

Kim, Y., Kim, Y. K., Lee, B. E., Lee, S. J., Ryu, Y. J., Lee, J. H., \& Chang, J. H. (2015). Ultralow-dose CT of the thorax using iterative reconstruction: Evaluation of image quality and radiation dose reduction. American Journal of Roentgenology, 204(6), 11971202. https://doi.org/10.2214/AJR.14.13629

Laqmani, A., Avanesov, M., Butscheidt, S., Kurfürst, M., Sehner, S., Schmidt-Holtz, J., Derlin, T., Behzadi, C., Nagel, H. D., Adam, G., \& Regier, M. (2016). Comparison of image quality and visibility of normal and abnormal findings at submillisievert chest CT using filtered back projection, iterative model reconstruction (IMR) and iDose $4^{\mathrm{TM}}$. European Journal of Radiology, 85(11), 1971-1979. https://doi.org/10.1016/j.ejrad.2016.09.001

Margerie-, Lambert, J., Martineau, A., Coulon, P., Kerviler, E. De, \& Al, D. E. M. E. T. (2016). Reducing Radiation Dose at Chest CT : Academic Radiology. https://doi.org/10.1016/j.acra.2016.05.019

Nagayama, Y., Oda, S., Nakaura, T., Tsuji, A., Urata, J., Furusawa, M., Utsunomiya, D., Funama, Y., Kidoh, M., \& Yamashita, Y. (2018). Radiation Dose Reduction at Pediatric CT: Use of Low Tube Voltage and Iterative Reconstruction.

Paper, P. white. (2013). Fast CT , Iterative Reconstruction Technique Yields High Image Quality at Low Dose. intel.

Patino, M., Fuentes, J. M., Singh, S., Hahn, P. F., \& Sahani, D. V. (2015). Iterative reconstruction techniques in abdominopelvic CT: Technical concepts and clinical implementation. American Journal of Roentgenology, 205(1), W19-W31. https://doi.org/10.2214/AJR.14.13402

Sakhnini, L. (2018). CT radiation dose optimization and reduction for routine head, chest and abdominal CT examination. Radiology and Diagnostic Imaging, 2(1), 14. https://doi.org/10.15761/rdi.1000120

Seeram, E. (2016). Computed Tomography Physical Principles, Clinical Applications, and Quality Control (fourth edi). Saunders company. http://evolve.elsevier.com/Seeram
Snell, R. (2012). Clinical Anatomy, an Ilustrated Teview With Questions and Explanation (hal. 1015-1017). Lippincot Williams \& Wilkins, Philadelphia.

Xin, X., Shen, J., Yang, S., Liu, S., Hu, A., Zhu, B., Jiang, Y., Li, B., \& Zhang, B. (2018). Improved Image Quality of Low-dose CT Combining With Iterative Model Reconstruction Algorithm for Response Assessment in Patients After Treatment of Malignant Tumor. Quantitative Imaging in Medicine and Surgery, 8(7), 648-657. https://doi.org/10.21037/qims.2018.08.05

Yan, C., Liang, C., Xu, J., Wu, Y., Xiong, W., Zheng, H., \& Xu, Y. (2019). Ultralow-dose CT with knowledge-based iterative model reconstruction ( IMR ) in evaluation of pulmonary tuberculosis: comparison of radiation dose and image quality. 1838.

Zhang, M., Qi, W., Sun, Y., Jiang, Y., Liu, X., \& Hong, N. (2018). The role of imaging in screening special feature: Full Paper Screening for lung cancer using submillisievert chest $C T$ with iterative reconstruction algorithm: image quality and nodule detectability. September 2017, 1-7. 